\title{
https://doi.org/10.34142/23129387.2019.60.09
}

\author{
UDC 159.9:37.015.3:372.881.1:378.018.43 \\ ORCID 0000-0002-5657-6477 \\ ORCID 0000-0002-8857-3107
}

\section{SELF-COGNITION AS A KEY FACTOR OF E-LEARNING ONLINE}

\author{
Natalya B. Turlakova, ${ }^{1 A B C D E}$, Dorin Festeu ${ }^{2 A B D}$ \\ ${ }^{I}$ candidate of psychological sciences,
}

Kharkiv National University of Civil Engineering and Architecture, Ukraine, Kharkiv

E-mail: nataturlakova90@gmail.com

2 doctor of philosophy, professor Buckinghamshire New University,

Great Britain, Buckinghamshire

E-mail: Dorin.Festeu@bucks.ac.uk

Authors' Contribution:

A - Study design; B - Data collection; C - Statistical analysis; D - Manuscript Preparation; E - Funds Collection.

Aim of the study: The article is devoted to the use of the psychological construct of self-cognition in the framework of traditional university education and e-learning online as a factor for increasing the effectiveness of student's cognitive and personal development.

Results: It emphasizes the relevance of self-cognition, which can be one of the main ways "to survive" for the young generation in the situation of quick adaptation necessity within a fast changing society and interaction with it. Such situation is typical for the period of the dynamic social transformations. This is connected with the processes of globalization and informatization, which determine the mode of human existence in the modern world. The phenomenon of self-cognition has been studied for many years in philosophy, and also in cognitive and humanistic psychology. But in spite of the rich values of these studies, it was not possible to find 
methods of the self-cognition targeted application within students' training as an effective means of their cognitive and personal development. Unfortunately the important role of the self-cognition has remained unnoticed within traditional university education. Self-development seems to be a spontaneous process, and so is self-cognition. At the same time, the latest information technologies, e-platforms and online learning methods are increasingly involved into modern life. They allow the creation of qualitatively new individual training e-environments and the development of individual computer training programmes, providing previously inaccessible opportunities for the effective personal development. The inclusion of the targeted self-cognition into the training process creates conditions which allow students to become the subject and the object of their own learning activities. In this regard, it is necessary to uncover the psychological mechanisms of the self-cognition, which are dictated by the need to overcome the imbalance between actual and necessary knowledge that implies the existence of knowledge about oneself.

Conclusions: The article presents innovative methods and tools created for the implementation of self-cognition within the training as well as for a high-quality feedback system and evaluation of the results of the educational activities.

Keywords: targeted self-cognition, meta-capacity to self-cognition, psychological mechanisms of the self-cognition, individual training $e$ environment, individual computer training programme, heuristic dynamic "Model of personality development factors interaction" (MDFI), feedback instruments, evaluation innovative technologies.

\section{Самопізнання як ключовий фактор е-навчання онлайн Наталія Б. Турлакова ${ }^{1}$, Дорін Фестеу ${ }^{2}$ \\ ${ }^{1}$ Харківський Національний Університет Будівництвва та Архітектури, м. Харків, Украӥна \\ ${ }^{2}$ Бакінгемширський Новий університет, м. Бакінгемшир, Велика Британія}

Mета статті: Стаття присвячена використанню психологічного конструкту самопізнання в рамках традиційного навчання у ЗВО $i$ е-навчання он-лайн як фактора підвищення ефективності когнітивного і особистісного розвитку студента.

Результати: Підкреслюється актуальність самопізнання, яке може виступити одним з основних способів «виживання» молодого 
покоління в ситуації необхідності швидкого пристосування до мінливого сочіуму і взаємодї̈ з ним. Такий стан речей характерний для сучасного періоду динамічних сочіальних трансформацій. Це пов'язано з процесами глобалізації та інформатизації, які визначають спосіб існування людини в сучасному світі. Феномен самопізнання вивчався протягом багатьох років в філософї, а потім в когнітивної та гуманістичної психологї. Але, незважаючи на багатство циих досліджень, виявити методики цілеспрямованого застосування самопізнання при навчанні студентів як ефективного засобу ї когнітивного та особистісного розвитку не вдалося. На жаль, в традииійному університетському освіті важлива роль самопізнання так $i$ залишилася непоміченою. Саморозвиток відбувається спонтанно, а самопізнання здійснюеться стихійно. У той же час новітні інформаційні технологї, е-платформи $і$ методики навчання он-лайн, все більше входять в сучасне життя, дозволяють створити якісне нове індивідуальне навчальну е-середовище $i$ підібрати індивідуальну комп'ютерну програму навчання, щзо надає раніше недоступні можливості для ефективного розвитку особистості. Включення иілеспрямованого самопізнання в навчальний прочес дозволяє створити умови, при яких студент стає суб'єктом, об'єктом i предметом своєї навчальної діяльності. У зв'язку з ичим виникає необхідність розкриття психологічних механізмів самопізнання, яка диктується потребою в подоланні дисбалансу між актуальним $i$ необхідним знанням, щзо передбачає наявність знань про себе.

Висновки: У статті описуються інноваційні методики $i$ інструменти, створені для введення самопізнання в навчання, а також для якісної системи зворотного зв'язку і евалюаиії результатів навчальної діяльності.

Ключові слова: цілеспрямоване самопізнання, метаздібність до самопізнання, психологічні механізми самопізнання, індивідуальне навчальне е-середовище, індивідуальна комп'ютерна програма навчання, евристична динамічна «Модель взаємодї факторів розвитку особистості» (МВФР), інструменти зворотного зв'язку, інноваційні технологї евалюації.

Introduction. Global transformations in the social environment and development of the information technologies field impose the new requirements to the profile of a modern specialist and dictate the need for rapid mastering of multidisciplinary knowledge, competence and multiprofile specialization (Sergeyeva \& Barber, 2016). There 
seems to be a danger that the general trend of obtaining digital information via Internet may decrease the value of the traditional forms of education because they seem to be faster and allow quick access to the necessary information. The quality and reliability of this kind of "knowledge" is often under doubt. The higher education system is faced with the task of developing digital forms of acquiring knowledge that will allow to provide high-quality and adequate knowledge for the student in a convenient and familiar e-format. These new e-formats should help to individualize training by creating for the student his/ her own e-learning environment and training program taking into account his/ her own aims, senses and needs.

However, as pointed out by professor Tetyana Sergeyeva (Sergeyeva, 2017a) in her article, universities prefer to proceed from existing opportunities using ready-made training platforms, adapting training courses to the technical capabilities of the platforms. Also, the limited interdisciplinary competence led to the recreation of the traditional courses using technical means only and with little gain in the quality and efficiency of the training. Unfortunately at current moment we should accept the fact that our expectations concerning e-learning contribution to the university education have been met to a very small extent.

We propose the solution to the problem by involving selfcognition into e-learning and simulating the e-learning environment and developing training activities on the basis of the psychological mechanisms and principles of the self-cognition. The imbalance between existing and required knowledge and skills will be addressed with the help of knowledge about himself/ herself (Tytarenko, 2003). This can be possible by the self-cognition involvement to the process of assessing the available resources to satisfy requested personal and cognitive senses. Unfortunately such practice is not implemented within the traditional university education. Despite numerous studies of the self-cognition phenomenon (Turlakova, 2007), its use in the traditional university education as well as in the new e-learning approach is not sufficiently implemented. 
The requirement to self-cognition is particularly acute in online learning, since it is extremely important to assess accurately the available personal resources, and select training strategies for satisfying personal senses. It is possible to develop detailed tuning of the individual training program by the self-cognition inclusion choosing the optimal mode, regime and training strategy. The involvement of the psychological mechanisms to the training process with the use of self-cognition at all stages of learning activities (Turlakova, 2018) helps to optimize this process and create the individual training environment, taking into consideration cognitivesense orientation.

The theoretical significance of the research consists in revealing the psychological principles and mechanisms of the self-cognition process within e-learning online.

The practical relevance of the work consists in the development of an innovative methodology based on the inclusion of selfcognition at all stages of e-learning online to improve its effectiveness. The new methodology is based on creating feedback instruments for assessment/ self-assessment and training process management/ self-management mastering subject knowledge and skills as well as on tracking personal development.

Aim. Social, educational, scientific and practical importance of e-learning has determined the purpose of the research, which is to deploy the psychological mechanisms of self-cognition and to develop technologies for its implementation in the e-learning online process in order to increase the effectiveness of student's selfdevelopment.

The object of the research is a person who discovers himself/ herself by learning a subject utilising the innovative format of elearning online.

The subject of the research is the psychological mechanisms, determinants, principles and technologies of self-cognition as a cognitive-sense basis of students' self-development under the conditions of e-learning online.

The tasks of the research are the following:

- formulation of a hypothesis that the self-cognition increases the effectiveness of students' cognitive and personal development; 
- development of the dynamic heuristic model using selfcognition to optimize the training process online and detailed tuning of the learning environment and individual training programme;

- development of the technology of self-cognition inclusion into e-learning online;

- development of the feedback instruments and complex evaluation of cognitive and personal development for student's interaction with the e-learning environment online;

- assessment of dynamics of the meta-capacity to selfcognition development, student's personal and cognitive characteristics development in terms of use different learning strategies.

Methodology of research. Theoretical research methods such as theoretical and methodological analysis of the problem, systematization and generalization of the materials on the problem, presented in the Ukrainian and foreign scientific literature, were used in the research. The following empirical research methods were used: natural observation, individual interviews, questionnaires, surveys, testing, experiment, content analysis. The obtained data were proceeded by mathematical processing (correlation, factor, comparative analysis), followed by qualitative interpretation and generalization of the content.

Research of the problem of students' meta-capacity to selfcognition development in the context of e-learning online allowed the classification of existing problems as methodological, educational and psychological. Correlation analysis identified significant positive relationship between the level of meta-capacity to self-cognition development and number of sense, cognitive, personal and emotional factors within e-learning online. Factor analysis allowed the identification of symptom complexes, united into threefactor model: the first factor was "self-control - suspiciousness", which characterized behavior regulation; the second factor was "friendliness - hostility", which described student's attitude to the elearning environment; the third factor was "adequacy of selfestimation - skepticism", which reflected real actual state of the arts. The identified factors confirmed the validity of a system approach to 
the targeted self-cognition of the personality within the training process online.

Reasons of the identified interrelations were defined in the course of the training experiment. Independent variable was represented by the training environment that was simulated in the frame of training strategy in the formats of the traditional training, blended traditional with e-formats or e-learning online developed on the base of psychological principles of the self-cognition. Dependent variable was represented by the targeted self-cognition as a factor for increasing efficiency of students' cognitive and personal development, which was measured at the sense, cognitive and activity levels (Turlakova, 2009).

Authors' original methods, models, and feedback instruments and complex evaluation techniques within longitude training experiment were used. They were the following (Turlakova \& Sergeyeva, 1999): "Model of personality development factors interaction" (MDFI), "Individual development card" (Turlakova, 1999), "Learning diary" (Turlakova, 2015b), "Technique of cognitive structures overlay" (Turlakova, 2015b), "Comparative method for analysis of effectiveness of the capacity to self-cognition development with the type of personality" (Turlakova, 2015b), "Transformation map of personality complex development to selfcognition resource" (Turlakova, 2015b), "Questionnaire for identifying personality patterns to select learning strategies" (Turlakova, 2015b), "Questionnaire for identifying level of selfcognition and student's cognitive-personal resources" (Turlakova, 2015b), "Questionnaire for identifying sense component of the selfcognition" (Turlakova, 2015b), "Matrix of self-cognition and training synergy" (Turlakova, 2015b), "Self-management e-learning online matrix - Progress Bar", "Self-evaluation matrix" (Sergeyeva, 2017b).

A special instrument for modeling the situation of self-cognition on the basis of its psychological mechanisms in the context of elearning online was developed. Heuristic dynamic "Model of personality development factors interaction" (MDFI) (Turlakova, 2015b) can create natural learning conditions and transform the selfcognition into all stages of the training activities. The model was 
developed on the basis of psychological and pedagogical principles of the Eco-Humanistic Theory of Self-development developed by Tetyana Sergeyeva (Sergeyeva, 2009) on the example of SmartEnglish $^{\text {online }}$ e-training programme. MDFI sets the algorithm of the existential circle of self-cognition and conducts the student through all its stages within training process for implementation of the developmental impact. The stages are the following:

1. Sense of learning event identification. There is a launch of the psychological mechanism of the self-cognition through the identification of the learning event personal meaning. The "principle of existentiality" operates, which provides the individualization of the learning process. It helps to center the training process mostly on student's personality (not on the learning subject). In this case the student becomes both the subject and the object of the self-cognition. The process expands from mastering the subject to the self-cognition within the process of this mastering. The powerful motive of the selfcognition is launched (Turlakova, 2002).

2. Selection of the training strategies. The "principle of optimization" of the self-cognition process operates in the form of individual resources assessment in the context of the possibility to realize personal senses through comparing student's individual cognitive-sense structure (ICSS) with the socially developed cognitive-sense structure (SCSS) (Sergeyeva, 2007). Comparison allows to identify discrepancies and set the zone of individual development.

3. Training strategies realisation. There is a transition to selfmanagement process. The "principle of subjectivity" operates here as a result of the synergistic interaction of the principles of "existentiality" and "optimality". The principle of subjectivity is associated with a proactive role, where the student acts both as object and subject of his/ her own development. Self-management is carried out on the basis of a meta-cognitive approach that develops subject and psychological meta-competence (knowledge about the subject structure and training strategies for its mastering; knowledge about the cognition process and personality as both the subject and the object of development). Self-management support depends on student's needs and includes the following modes: e-tutor -online 
training tutorials; self-tutor - self-management based on detailed instructions; tutor - assistance of the teacher, expert-tutor - assistance of the methodologist (Turlakova, 2015c)

4. Training strategies automation. At this stage, successful skills are automated and integrated into personal resources.

The isomorphism of this model provides an opportunity for research and management of the training process both for the students and for teachers and scientists.

A longitudinal training experiment was conducted under natural university education within e-learning online during 3 years based on e-training complex SmartEnglish ${ }^{\text {online }}$ on the e-platform STVteam, developed by Tetyana Sergeyeva in the frame of Eco-Humanistic Self-development Technology (Segeyeva, 2013). 300 students, postgraduates and teachers from Kharkiv universities aged from 17 to 45 years took part in the experiment.

Students were divided into 4 groups within the longitudinal training experiment: 1 control $(\mathrm{K})$ and 3 experimental (E1, E2, E3).

In the control group $\mathrm{K}$ the training was organized on the basis of traditional training, which was devoted to development of professional knowledge and skills within subject learning. Students got knowledge via ready-made format of lectures, cases, example with subsequent discussion at workshops. There was no orientation to the student's personal senses, self-cognition and individualization of the training.

In the experimental group E1 the training was organized on the platform STVteam.com using all forms of the described traditional training with partly implemented distance learning e-formats such as introductory lectures and practical control testing. Practical and control tasks were performed on the e-platform with the subsequent automatic verification of the results using a computer programme. Feedback was provided in the form of key answers.

In the experimental group E2 the training was organized on the basis of self-cognition situation simulation and use of its psychological mechanisms operating MDFI model. It allows to transform algorithm of the existential circle of self-cognition to the natural learning conditions. All psychological principles described earlier were involved. Discrepancies, found during use of 
"Technique of cognitive structures overlay", were taken into consideration for individual training programme development.. With the help of MDFI model students passed through all stages of the existential circle of cognition: identification of individual sense of learning event, assessment of the existing resources for to satisfy personal senses, selection of the training strategies for realization of identified senses, realization and feedback, automation of successful skills and their integration into personal resources. Meta-capacity to self-cognition was formed purposefully within existential context through the tasks of self-management of the self-development process.

In the experimental group E3 the training was based on etraining complex SmartEnglish ${ }^{\text {online }}$ on e-platform STVteam in a format of human-centred model, developed by Tetyana Sergeyeva on the basis of Eco-Humanistic Self-development Technology (Turlakova, Sergeyeva \& Demydiuk, 2018). The training strategy described for the group E2 was simulated also for group E3 but the additional self-management mode within e-learning format online was implemented. Interactive lectures SEO (Sergeyeva, 2018) set a strategic orientation to the ultimate goals in the form of metacognitive knowledge about the subject, about knowledge itself and about personality in the process of learning activities, which allowed the realization of self-management of the self-development process within the e-learning online. Meta-capacity to self-cognition was formed purposefully through the tasks of self-management of the process of self-development in the professional, social and existential contexts. New technical capabilities of the e-learning online format allowed to use all author's technologies, feedback instruments and evaluation package for proceeding automated system of self-management, self-control and self-assessment with prompt feedback working within online mode, for communication in the frame of training courses and forums.

Results. Empirical investigation of the targeted self-cognition as a factor for student's cognitive and personal effectiveness increasing within traditional and e-learning online produced the following results:

- On the sense level the evaluation criteria reflected the development of the personality senses within used training strategy. 
The figure indicators and the growth of the professional, social and existential senses development in the groups were respectively: in the group $\mathrm{K}=0.32(+0.01), 0.33(+0.03), 0.30(+0.02)$; in the group $\mathrm{E} 1=0.43(+0.12), 0.33(+0.03), 0.33(+0.05)$; in the group $\mathrm{E} 2=0.59$ $(+0.28), 0.57(+0.27), 0.57(+0.29)$; in the group E3 = $0.62(+0.31)$, $0.61(+0.31), 0.62(+0.34)$. The figures proved that subject-orientated strategies $\mathrm{K}$ and $\mathrm{E} 1$ did not support development of the student's senses irrespective of the training material delivering mode. Significant growth of the personality senses took place in the frame of targeted self-cognition strategies in the groups E2 and E3. Moreover, the development was more intensive with the implementation of the e-learning online mode in the group E3.

- On the cognitive level the evaluation criteria were the interconnection and interdependence between the effectiveness of self-cognition process and student's individual cognitive-sense structure (ICSS) in its part which was connected with the cognition of the outside world. The targeted self-cognition caused the following results linked with the growth of the ICSS development level: in the group E1 ICSS ${ }^{\text {sc }}=0.44(+0.17)$, in the group E2 ICSS ${ }^{\text {sc }}$ $=0.62(+0.35)$, in the group E3 ICSS ${ }^{\mathrm{sc}}=0.70(+0.43)$. In the group $\mathrm{K} \mathrm{ICSS}^{\mathrm{sc}}=0.39(+0.12)$. There was no targeted self-cognition within training process in the group $\mathrm{K}$. The figures proved that nearly all strategies provided student's ICSS ${ }^{\text {sc }}$ development but the growth was significantly higher within the human-centred training.

- On the activity level the evaluation criteria were the level of meta-capacities and meta-qualities formation. The figure indicators and the growth of meta-capacities such as making decision, synergetic interaction and self-development made up respectively: in the group $\mathrm{K}=0.42(+0.03), 0.33(+0.02), 0.39(0.02)$; in the group $\mathrm{E} 1=0.45(+0.05), 0.42(+0.06), 0.44(+0.06)$; in the group E2 $=0.57$ $(+0.21), 0.59(+0.23), 0.59(+0.23)$; in the group E3 = $0.66(+0.30)$, $0.63(+0.27), 0.65(+0.29)$. The figure indicators and the growth of meta-qualities such as proactivity, autonomy, objectivity, responsibility, creativity, flexibility and empathy made up respectively: in the group $\mathrm{K}=0.34(+0.02), 0.35(+0.01), 0.46$ $(+0.09), 0.31(+0.03), 0.33(+0.00), 0.32(+0.01), 0.31 \quad(+0.00)$; in the group $\mathrm{E} 1=0.35(+0.04), 0.35(+0.02), 0.40(+0.12), 0.37$ 
$(+0.03), 0.36(+0.03), 0.32(+0.00), 0.31(+0.00)$; in the group E2 $=$ $0.61(+0.28), 0.67(+0.29), 0.62(+0.25), 0.59(+0.21), 0.61(+0.22)$, $0.62(+0.21), 0.59(+0.19)$; in the group $\mathrm{E} 3=0.72(+0.35), 0.73$ $(+0.37), 0.66(+0.32), 0.61(+0.22), 0.62(+0.28), 0.61(+0.24), 0.58$ $(+0.18)$. The data reflected that the degree of self-cognition involvement to the training within various training strategies led to the formation of the various ways of activity according to the criteria of their consistency, awareness, intensity, individualization and, as a result, fast automation of knowledge. This was reflected on the effectiveness of the personal capacities and qualities development.

Discussion. Experimental research proved that the development of the meta-capacity to self-cognition under the condition of elearning online was possible optimizing the learning process at the expense of consistency and subjectivity. This meta-capacity significantly influenced on the effectiveness of student's cognitive and personal development optimizing training process by consistency and subjectivity. The student had the opportunity both to study an academic subject and himself/ herself within the process of knowledge acquisition. Quantitative indicators of the personal development as an object of self-cognition, which were obtained in the framework of the longitudinal training experiment, proved that the level of self-cognition inclusiveness to e-learning online affected the effectiveness of personal development at the sense (attitude), cognitive (reflection) and activity (activity methods) levels (Turlakova, 2015a).

We compared efficiency between traditional training and elearning online based on subject-centred or student-centred models. The data obtained revealed a slight effect of e-learning in the first models and a significant increase in efficiency in the second. Moreover, modern technical capabilities of e-learning online initiated a synergistic effect based on psychological mechanisms of selfcognition by strengthening of the principles of individualization, optimization and subjectivity.

Comparing our results with other investigations of the problem has identified the complexity because in modern scientific literature we did not find the psycho-pedagogical approaches to the system organization of e-learning online. In most cases even very 
authoritative authors (Clandfield \& Hadfield, 2017; McCarthy, 2016; Donald, 1993) propose quite efficient set of tools or packages of communicative strategies but not a systematic vision of e-learning methodology.

The use of the innovative technologies within e-learning online allowed the implementation of self-management and high-quality self-evaluation (Turlakova, Sergeyeva \& Demydiuk, 2008). The innovative technology "Smart Evaluation Package", developed on the basis of patterns of psychological mechanisms of self-cognition, allowed the monitoring of training activities results throughout the training (digital indicators of completeness, efficiency and accuracy of the subject task solving, frequency of accessions to supporting materials and tutorials, systematic training sessions on the platform) as well as self-management and training evaluation (histograms and profiles of cognitive-personal development, "Individual development card", "Learning diary", comparative histograms of the effectiveness of cognitive resources development).

The evaluation data obtained within the e-learning online was promptly reflected into the Evaluation Zone of the individual training program presented in the format of Progress Bar (Sergeyeva, 2017b) on STVteam training platform and processed in accordance with the formulas for calculating the integrated efficiency. It should be noted that the obtained indicators made it possible to identify the individual requirements for working out the training material and the establishment of the ideal training mode: if the "success chart" showed efficiency below $70 \%$, then it was necessary to return to the task and repeat attempts until the achievement of requested result, because admission to the next module assumed the successful completion of the previous one. Thus, the strategic orientation of self-development was set, where the result of the implementation of the previous task became the condition for the implementation of the subsequent one. The use of this technology simulated the gradual formation and automation of students' mental actions within elearning online training with their subsequent integration into the internal resources of the personality in the form of capacities and qualities. 
Conclusions. New technical capabilities contributed to the solving of the urgent problems of the university education including self-cognition into e-learning by simulating e-learning environment and developing training activities on the basis of the psychological mechanisms of self-cognition principles.

Simulating the natural process of self-cognition within training launched its psychological mechanisms, which determined the effectiveness of student's cognitive and personal resources development in the frame of e-learning online.

The consistency within e-learning online (Sergeyeva \& Nazymko, 1999) provided effective increase of the individual resources at each stage of the training activity that created new conditions for interaction between enriched resources with e-learning environment. It led to self-development of the personality.

The effectiveness of cognitive and personal development of students was determined by the training strategies used.

Effective training was possible in the framework of humancentred model (not the subject-centred model). The principle of individualization allowed the student to both act as the object and the subject of learning; cognize both the subject and himself/ herself within the training process of mastering the subject

The innovative "Model of personality development factors interaction" (MDFI) can create natural learning conditions and transform the self-cognition into all stages of the training activities in the e-learning online format.

Innovative technical feedback instruments and evaluation package provided high quality of student's interaction with the elearning online environment.

The prospect of the research could be the development of etechnologies and e-packages of training materials on the basis of psychological mechanisms of self-cognition for e-learning online.

\section{References}

Clandfield, L. \& Hadfield, J. (2017). Interaction Online. Cambridge: Cambridge University Press, 1-10.

McCarthy, M. (2016). The Cambridge Guide to Blended Learning for Language Teaching. Cambridge: Cambridge University Pres. 
Donald, A. N. (1993). Things that make us smart: defending human attributes in the age of the machine. Boston, MA, USA: Addison-Wesley Longman Publishing Co.

Sergeyeva, T. \& Barber, J. (2016). Developing generic competences in learning to learn, Kharkiv: "Operativnaya poligrafiya".

Sergeyeva, T.V. (2017a). Orientation to personality qualities while developing training courses and selecting teams for multidisciplinary international projects. Visnyk KNPU imeni H. S. Skovorody. Psykholohiia H.S. Skovoroda KhNPU Herald. Series "Psychology", 57, 282-292.

Sergeyeva T.V., Nazymko E.V. (1999). Realizatsia printsipov sistemnosti i kommunikativnosti na osnove technologii smyslovoi interpretatsii [Realization of the systematization principles on the basis of meaning interpretation technology]. Vestnik KhGU . Seria "Psikhologiya". Psychology - KhGU Bulletin. Series "Psychology", 432, 301-306. [in Russian].

Sergeyeva, T.V. (2007). Metodika nalozheniya kognitivnykh skhem [Cognitive schemes overlay technique]. Visnyk Kharkivskoho natsionalnoho universytetu im. V.N. Karazina - Bulletin of Kharkiv National University. Series psychology, 771, 227-236. [in Russian].

Sergeyeva, T.V. (2009). Eko-Gumanisticheskoye samorazvitiye: monografiya [Eco-Humanistic self-development], Kharkov: Blok [in Russian].

Sergeyeva, T.V. (2013). Obuchayushchaya tekhnologiya tselenapravlennogo kognitivnogo i lichnostnogo samorazvitiya studentov $\mathrm{v}$ usloviyakh VUZa [Training technology of purposeful cognitive and personal self-development of students under university condition]. Humanitarnyi visnyk DVNZ "Pereiaslav-Khmelnytskyi derzhavnyi pedahohichnyi universytet im. H. S. Skovorody”.: Tematychnyi vypusk "Problemy empirychnykh doslidzhen u psykholohii" - Humanitarian Herald of the State Higher Educational Institution " H.S. Skovoroda Pereyaslav-Khmelnytsky State Pedagogical University", 2 (31). K.: Hnozys, 205-212. [in Russian].

Sergeyeva, T.V. (2017b). Tekhnika indyvidualizatsii E-kursiv navchannia (PB) [Individualising technique of e-training courses (PB)]. Kharkivskyi osinnii marafon psykhotekhnolohii: Materialy naukovopraktychnoi konferentsii (Kharkiv, 28 zhovtnia 2017) - Kharkov autumn marathon of Psychotechnologies: Proceedings of the conference (Kharkov, October 28, 2017), 108. Kharkiv: Vid-vo "Disa plius" [in Ukrainian].

Sergeyeva, T.V. (2018). «SmartEnglishonline (SEO) - innovatsiine navchannia onlain, yake tsentrovane na studenti» [SmartEnglishonline 
(SEO) - an innovative online training focuced on a student]. Problemy optymalnoho funktsionuvannia osobystosti $u$ suchasnykh umovakh: materialy mizhnarodnoi naukovo-praktychnoi konferentsii (Kharkiv, 25 zhovtnia 2018) - Problems of optimal functioning of the individual in modern conditions: Proceedings of the International Scientific Conference (Kharkov, October 25, 2018), 175-176. Kharkiv: KhNU im. V.N. Karazina [in Ukrainian].

Tytarenko T. M. (2003). Zhyttevyi svit osobystosti u mezhah $i$ za mezhamy budennosti [The world of personality within and beyond the ordinary]. Kyiv: Lybid, 315-322. Kyiv [in Ukrainian].

Turlakova N.B., Sergeyeva T.V. (1999). Systema zvorotnoho zviazku yak zasib samokontroliu, samootsinky i samokeruvannia $\mathrm{v}$ umovakh navchannia [The feedback system as a means of self-control, self-evaluation and self-management in the learning environment]. Naukovi zapysky Kharkivskoho viiskovoho unyversytetu: sotsialna filosofiia, pedahohika, psykholohiia - Scientific notes of Kharkiv Military University: social philosophy, pedagogy, psychology, V, 175-179. Kharkiv [in Ukrainian].

Turlakova N.B. (1999). Vidbytok intelektualnyh, piznavalnyh i osobystistnyh harakterystyk u kompiuternii karti indyvidualniho rozvytku [Reflection of intellectual, cognitive and personal characteristics in the computer card of the individual development]. Naukovyi visnyk KhDPU. Psyhologichni nauky - Scientific Bulletin of the KhSPU. Psychological sciences, 3, 155-158. Kharkiv [in Ukrainian].

Turlakova N.B. (2002). Usvidomlennia mety, motyvu i strategii uchbovo-piznavalnoi diialnosti $\mathrm{v}$ protsessi planuvannia indyvidualnoi programmy navchannia $\mathrm{v}$ tehnolohii samorozvytku [Awareness of the purpose, motive and strategy of training- cognitive activity in the process of individual training program planning within the self-development technology]. Visnyk Kharkivskogo natsionalnogo universytetu. Seriia psyholohiia - Bulletin of Kharkiv National University. Series psychology, 576, 202-204. [in Ukrainian].

Turlakova N.B. (2007). Istoricheskii aspect izucheniia psihologicheskogo konstrukta samopoznaniia [The historical aspect of research of the self-cognition psychological construct]. Visnyk Kharkivskogo natsionalnogo universytetu. Seriia psyholohiia. - Bulletin of Kharkiv National University. Series psychology, 771, 267-270. [in Russian].

Turlakova N.B., Sergeyeva T.V., Demydiuk O.B. (2008). Tehnologiia kompleksnoi evaluatsii [Technology of complex evaluation]. Innovatsiini tehnolohii: zbirnyk naukovyh prats. - Innovative technologies: bulletin of researches, 108-111. Kharkov [in Russian]. 
Turlakova N.B. (2009). Eksperimentalnoe issledovanie samopoznania kak kognitivnogo komponenta samorazvitiia [Experimental research of selfcognition as a cognitive component of self-development]. Naukovyi vistnyk pivdennoukrainskoho derzhavnoho pedagohichnogo universytetu im. K.D. Ushinskoho. Spetsialnyi vypusk «Psyholohia osobystosti: teoriia, dosvid, praktyka». - Scientific Bulletin of the Southern Ukrainian State Pedagogical University named after. K.D. Ushinsky. Special issue "Psychology of Personality: Theory, Experience, Practice", 40-49. [in Russian].

Turlakova N.B. (2015a). Doslidzhennia samopiznannia iak kognityvna osnova samorozvytku osobystosti [Research of self-cognition as a cognitive basis of the personality self-development]. Naukovyi ohliad. - Scientific review. 6 (16), 123-133. Kyiv [in Ukrainian].

Turlakova N.B. (2015b). Samopiznannia iak kognityvna osnova samorozvytku osobystosti studenta $\mathrm{v}$ umovah socialnyh transformatsii [Self-cognition as cognitive bases of student personality self-development under condition of social transformations]. (Dysertatsia na zdobuttia naukovoho stupenia kandydata psyholohichnyh nauk. - Thesis for a candidate degree in psychological sciences), 71-94. Kharkiv [in Ukrainian].

Turlakova N.B. (2015c). Metodika sozdania uchebnyh materialov dlia e-learning [Methods of e-learning educational materials development]. Suchastnyi pidhid do upravlinnia iakistiu pidgotovky fahivtsiv $v$ umovah tehnichnogo universytetu. Materialy 70-i naukovo-metodychnoi konferentsii. - Modern approach for qualitative management of the specialists training within technical university. The materials of the 70th scientific conference, 91-94. Kharkiv [in Ukrainian].

Turlakova N.B. (2018). Actyvizatsia psycholohgichnyh mehanizmiv rozvytky samopiznannia $\mathrm{v}$ ekzistentsiinomy koli povsiakdennosti [Activation of psychological mechanisms of self-cognition within the existential circle of everydayness]. Naukovyi vistnyk Khersonskoho derzhavnoho universytetu. Seria «Psycholohichni nauky».Zhurnal vklucheno do mizhnarodnoi naukometrychnoi bazy Index Copernicus International (Respublica Polzcha).- Scientific Bulletin of the Kherson State University. Series "Psychological Sciences". The Scientific Bulletin is included into the international science-metric database Index Copernicus International (Republic of Poland), 1/2018, 87-92. Kherson [in Ukrainian].

Turlakova N.B., Sergeyeva, T.V., Demydiuk O.B. (2018). Rozvytok pamiati studentiv na osnovi innovatsiinyh mnemotehnik е-кursu SmartEnglish $^{\text {online }}$ [Development of students' memory on the basis of innovative mnemotechnics of SmartEnglish ${ }^{\text {online }}$ e-training course]. Problemy optymalnoho funktsionuvannia osobystosti $u$ suchasnykh 
umovakh: materialy mizhnarodnoi naukovo-praktychnoi konferentsii (Kharkiv, 25 zhovtnia 2018) - Problems of optimal functioning of the individual in modern conditions: Proceedings of the International Scientific Conference (Kharkov, October 25, 2018), 175-176. Kharkiv: KhNU im. V.N. Karazin [in Ukrainian].

Original manuscript received March, 17, 2019

Revised manuscript accepted March, 25, 2019 